Provided for non-commercial research and education use. Not for reproduction, distribution or commercial use.

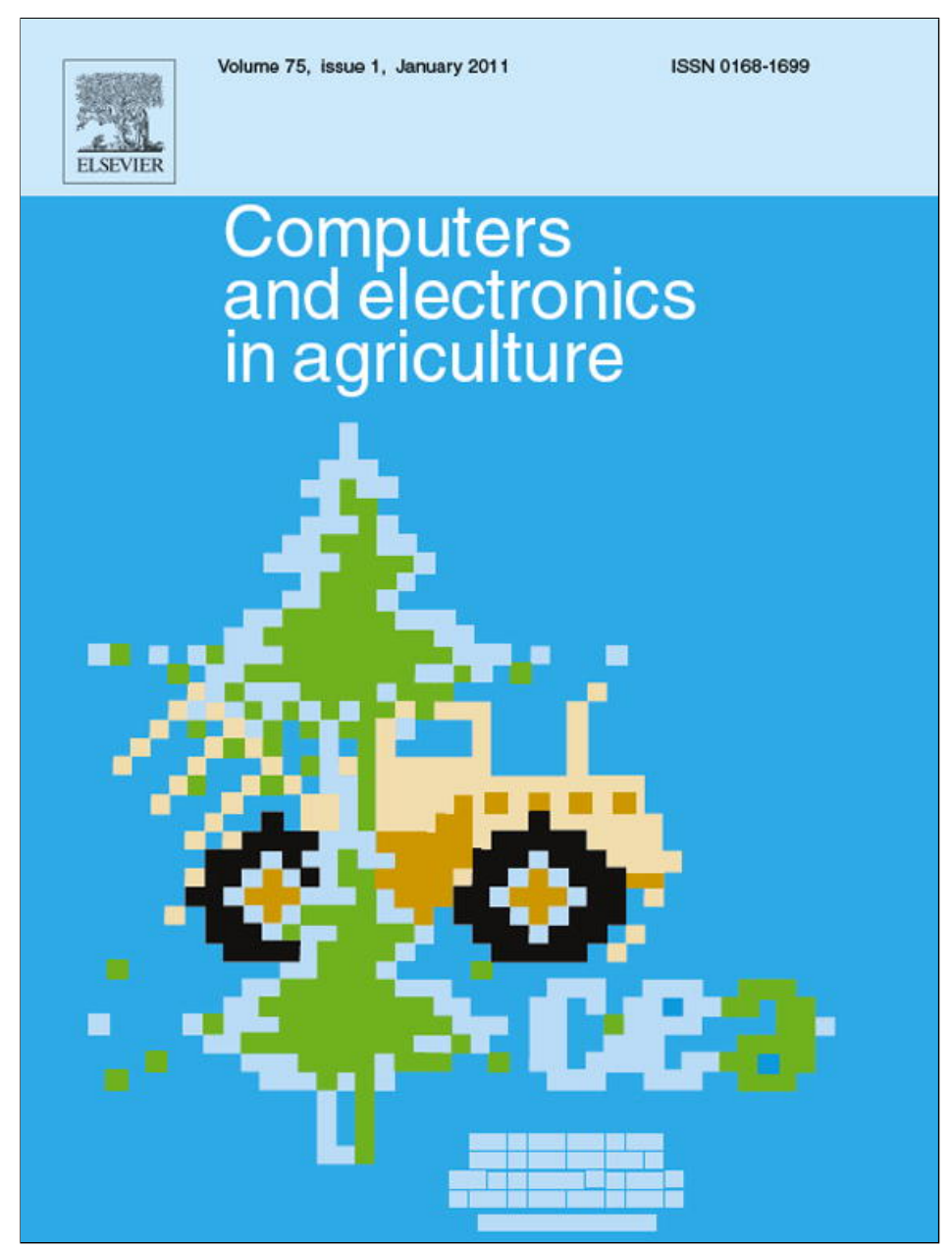

(This is a sample cover image for this issue. The actual cover is not yet available at this time.)

This article appeared in a journal published by Elsevier. The attached copy is furnished to the author for internal non-commercial research and education use, including for instruction at the authors institution and sharing with colleagues.

Other uses, including reproduction and distribution, or selling or licensing copies, or posting to personal, institutional or third party websites are prohibited.

In most cases authors are permitted to post their version of the article (e.g. in Word or Tex form) to their personal website or institutional repository. Authors requiring further information regarding Elsevier's archiving and manuscript policies are encouraged to visit:

http://www.elsevier.com/copyright 


\title{
The role of RFID in agriculture: Applications, limitations and challenges
}

\author{
Luis Ruiz-Garcia*, Loredana Lunadei \\ Laboratorio de Propiedades Físicas y Tecnologías Avanzadas en Agroalimentación, Universidad Politécnica de Madrid, ETSI Agrónomos, Edificio Motores, Avda. Complutense s/n, \\ 28040 Madrid, Spain
}

\section{A R T I C L E I N F O}

\section{Article history:}

Received 24 November 2010

Received in revised form 30 July 2011

Accepted 20 August 2011

\section{Keywords:}

RFID

Precision agriculture

Animal identification

Food traceability

Cold chain

\begin{abstract}
A B S T R A C T
The recent advances in RFID offer vast opportunities for research, development and innovation in agriculture. The aim of this paper is to give readers a comprehensive view of current applications and new possibilities, but also explain the limitations and challenges of this technology.

RFID has been used for years in animal identification and tracking, being a common practice in many farms. Also it has been used in the food chain for traceability control. The implementation of sensors in tags, make possible to monitor the cold chain of perishable food products and the development of new applications in fields like environmental monitoring, irrigation, specialty crops and farm machinery.

However, it is not all advantages. There are also challenges and limitations that should be faced in the next years. The operation in harsh environments, with dirt, extreme temperatures; the huge volume of data that are difficult to manage; the need of longer reading ranges, due to the reduction of signal strength due to propagation in crop canopy; the behavior of the different frequencies, understanding what is the right one for each application; the diversity of the standards and the level of granularity are some of them.
\end{abstract}

(c) 2011 Elsevier B.V. All rights reserved.

\section{Introduction}

RFID is entering in a new phase and is said to improve the performance of many agricultural processes. The recent advances offer vast opportunities for research, development and innovation in agriculture. This is the consequence of lowering costs of ownership, engineering increasingly smaller sensing devices and the achievements in radio frequency technology and digital circuits.

Also, RFID shows several differences and advantages over previous technologies like barcode. RFID tags do not require direct line of sight to the reader and thus can be embedded in a item, placed inside the packing or injected inside the body of animals (Finkenzeller, 2004). RFID has longer reading range than barcodes; they can be read at dozens or even more than $100 \mathrm{~m}$ of distance. RFID readers can interrogate, or read, tags much faster; read rates of more than 100 tags per second are possible (new developments promise up to 1000 tags per second). RFID tags have write memory capability (5 tags per second) and can store data; up to $4 \mathrm{kB}$ in passive, $1 \mathrm{MB}$ in active tags (ECPGlobal, 2008).

The first applications were developed just for identification; however, growing interest in other possible applications has led to the development of a new range RFID devices outfitted with

\footnotetext{
* Corresponding author. Tel.: +34 913365 862; fax: +34 913365845.

E-mail address: luis.ruiz@upm.es (L. Ruiz-Garcia).

URL: http://www.lpftag.upm.es (L. Ruiz-Garcia).
}

sensors that extend the range of application (Want, 2004). Current temperature monitoring systems like strip chart recorders or temperature dataloggers are usually expensive and not automated, thus requiring manual inspection. RFID devices are more accurate and can be read without the need of visual contact (Abad et al., 2009). There are commercial active and semi-passive tags that can collect temperature information (Amador et al., 2008; Jedermann et al., 2009). Other semi-passive tags outfitted with sensor are under development, like humidity (Chang et al., 2007; Abad et al., 2009), shock/vibration (Todd et al., 2009), light (Cho et al., 2005; Abad et al., 2009), pH (Murković and Steinberg, 2009) and concentration of gases, such as acetaldehyde or ethylene (Vergara et al., 2006). Biosensor tags are also being investigated. These tags could be used for detecting bacterial contamination on food products along the supply chain (Wentworth, 2003).

The aim of this paper is to review the numerous applications that utilize RFID in agriculture and food industry and to classify them in appropriate categories. The analysis of their characteristics and contributions could be useful for perceiving new applications or relevant research opportunities.

The current applications of RFID in agriculture are detailed in Section 2, including food traceability, livestock, precision farming and cold chain experiences. Section 3 describes various challenges and limitations, like operation in harsh environments, reading range, management of huge volume of data produced and the level of granularity. Finally, Section 4 states some conclusions about the state of art and the future trends of this technology. 
Table 1

Summary of recent RFID applications in agriculture.

\begin{tabular}{|c|c|c|}
\hline Category & Subject & References \\
\hline Food traceability & $\begin{array}{l}\text { Agro-food logistics and supply chain management } \\
\text { processes }\end{array}$ & $\begin{array}{l}\text { Jones et al. (2004), Angeles (2005), Twist (2005), Attaran } \\
\text { (2007), Ngai et al. (2007), Sugahara (2009) }\end{array}$ \\
\hline Food traceability & $\begin{array}{l}\text { Quality oriented tracking and tracing systems } \\
\text { FEFO }\end{array}$ & $\begin{array}{l}\text { Koutsoumanis et al. (2005), Emond and Nicometo } \\
\text { (2006), Scheer (2006) }\end{array}$ \\
\hline Livestock & Animal identification & $\begin{array}{l}\text { Morrison and Curkendall (2001), Finkenzeller (2004), } \\
\text { Mun Leng et al. (2005), Trevarthen (2007), Chansud et al. } \\
\text { (2008), Reiners et al. (2009), Wisanmongkol and } \\
\text { Pongpaibool (2009), Voulodimos et al. (2010) }\end{array}$ \\
\hline Livestock & $\begin{array}{l}\text { Measuring core body temperature with RFID sensing } \\
\text { devices injected into the animal }\end{array}$ & Opasjumruskit et al. (2006), Marsh et al. (2008) \\
\hline Climate monitoring & $\begin{array}{l}\text { Lab prototype for wireless measurement of soil } \\
\text { temperature }\end{array}$ & Hamrita and Hoffacker (2005) \\
\hline Precision irrigation & Smart sensor array for scheduling irrigation in cotton & Vellidis et al. (2008) \\
\hline Greenhouses & $\begin{array}{l}\text { Remote sensing with RFID, spectral imaging and } \\
\text { environmental sensing in a greenhouse }\end{array}$ & Yang et al. (2008) \\
\hline Greenhouse & $\begin{array}{l}\text { RFID tracking of potted plants from nursery to } \\
\text { distribution }\end{array}$ & Barge et al. (2010) \\
\hline Horticulture & Fruit harvesting & Ampatzidis and Vougioukas (2009) \\
\hline Horticulture & Longevity of RFID in citrus trees & Bowman (2010) \\
\hline Horticulture & $\begin{array}{l}\text { Implanting RFID into Prunus spp. for supporting sanitary } \\
\text { certification }\end{array}$ & Luvisi et al. (2011) \\
\hline Precision viticulture & Electronic management of vineyards & Luvisi et al. (2010a,b) \\
\hline Farm machinery & Automatic machine identification in cotton harvesting & Sjolander et al. (2011) \\
\hline Cold chain & $\begin{array}{l}\text { Microbial growth models combine with information } \\
\text { from active RFID }\end{array}$ & McMeekin et al. (2006) \\
\hline Cold chain & $\begin{array}{l}\text { RFID tags with embedded temperature sensors and a } \\
\text { temperature-managed traceability starter kit }\end{array}$ & Ogasawara and Yamasaki (2006) \\
\hline Military food chain & $\begin{array}{l}\text { Development of RFID temperature tracking systems for } \\
\text { combat feeding logistics }\end{array}$ & Amador and Emond (2010) \\
\hline Cold chain & $\begin{array}{l}\text { Monitoring cold chain of frozen goods using semi- } \\
\text { passive and active RFID instrumented with temperature } \\
\text { sensors }\end{array}$ & Gras (2006) \\
\hline Cold Chain & $\begin{array}{l}\text { Temperature tracking in an international shipment of } \\
\text { pineapples from a packing house, in Costa Rica, to a } \\
\text { wholesale storage, in USA }\end{array}$ & Amador et al. (2009) \\
\hline Cold chain & $\begin{array}{l}\text { RFID smart tag instrumented with light, temperature } \\
\text { and humidity sensors for the fresh fish logistic chain }\end{array}$ & Abad et al. (2009) \\
\hline Cold chain & $\begin{array}{l}\text { Monitoring of } 16 \text { multi-compartmental trucks using } \\
\text { semi-passive RFID instrumented with temperature } \\
\text { sensors }\end{array}$ & Jedermann et al. (2009) \\
\hline Air cargo & $\begin{array}{l}\text { Radio frequency interactions with air cargo container } \\
\text { materials for real time cold chain monitoring }\end{array}$ & Laniel et al. (2010) \\
\hline Intermodal transport & $\begin{array}{l}\text { A system for intelligent containers combining wireless } \\
\text { sensor networks and RFID }\end{array}$ & Jedermann et al. (2006) \\
\hline Intermodal transport & $\begin{array}{l}\text { 3-D mapping of RFID signal strength inside a } 12 \mathrm{~m}\left(40^{\prime}\right) \\
\text { refrigerated marine container }\end{array}$ & Laniel et al. (2008) \\
\hline
\end{tabular}

\section{RFID applications in agriculture}

The development of RFID applications in agro-food has attracted considerable research efforts in the last years. However, some areas have been developed faster than others. For example, there are several applications in livestock or cold chain monitoring and just a few in farm machinery (see Tables 1 and 2). Fig. 1 and Table 2 show the applications included in this paper, classified by topic, power source and frequency. Both passive and active tags are being used in Agriculture. Passive tags only give information about identification and tracking, for sensing applications it is necessary to use semi-passive or active tags.

Choosing the right frequency: Despite the fact that some of the authors do not specify the frequency of the systems, we found the higher amount of applications at LF (Low Frequency) and UHF (Ultra High Frequency) bands. The LF band is used mostly for implants in trees and animal identification systems, according to the ISO 11784 and ISO11785 standards. UHF frequencies typically offer better range and can transfer data faster than lowand high-frequencies. But they use more power and are less likely to pass through materials. The use of other frequencies than
$2.4 \mathrm{GHz}$ avoids interference from water and the metal, and thus is typical for irrigation, greenhouse or cold chain applications. Low-Frequency tags use less power and are better able to penetrate non-metallic substances. In general, the higher the frequency, the longer the communication range, and the faster the communication, this means that more data can be transmitted. In near field applications where is possible to have lots of tags it might be better to have a tag with low read range to avoid false positive reads. In other applications, like crop monitoring, it is better to choose a long read range to optimize the read performance (see Table 3 ).

\subsection{Food traceability}

RFID has been successfully applied to traceability control and supply chain management processes because of its ability to identify, categorize, and manage the flow of goods (Jones et al., 2004; Angeles, 2005; Twist, 2005; Attaran, 2007; Ngai and Riggins, 2008; Sarac et al., 2010). The use of the EPC (Electronic Product Code) standard improves the efficiency in the supply chain and allows the exchange of information between different companies. The lowering cost of RFID will provide the opportunity to track 
Table 2

Classification of RFID applications by topics, power source and frequency.

\begin{tabular}{|c|c|c|c|c|c|}
\hline \multirow[t]{2}{*}{ Power source } & \multicolumn{5}{|l|}{ Frequency } \\
\hline & $110-134.2 \mathrm{kHz}$ & $13.56 \mathrm{MHz}$ & $433 \mathrm{MHz}$ & $915 \mathrm{MHz}$ & $2.4 \mathrm{GHz}$ \\
\hline Passive & $\begin{array}{l}\text { Livestock } \\
\text { (Opasjumruskit } \\
\text { et al., 2006; Marsh } \\
\text { et al., 2008; } \\
\text { Voulodimos et al., } \\
\text { 2010) } \\
\text { Horticulture } \\
\text { (Bowman, 2010; } \\
\text { Luvisi et al., 2011) } \\
\text { Greenhouse } \\
\text { (Barge et al., 2010) } \\
\text { Viticulture (Luvisi } \\
\text { et al., 2010a,b) }\end{array}$ & Livestock (Reiners et al., 2009) & & $\begin{array}{l}\text { Livestock (Mun Leng et al., 2005; } \\
\text { Chansud et al., 2008; Wisanmongkol } \\
\text { and Pongpaibool, 2009) } \\
\text { Food traceability (Ngai et al., 2007) } \\
\text { Intermodal transport (Laniel et al., } \\
\text { 2008) } \\
\text { Horticulture (Ampatzidis and } \\
\text { Vougioukas, 2009) }\end{array}$ & $\begin{array}{l}\text { Intermodal transport } \\
\text { (Laniel et al., 2008) }\end{array}$ \\
\hline Semi-passive & & $\begin{array}{l}\text { Climate monitoring (Hamrita and } \\
\text { Hoffacker, 2005) } \\
\text { Intermodal transport (Jedermann } \\
\text { et al., 2006) } \\
\text { Cold chain (Gras, 2006; Abad et al., } \\
\text { 2009; Amador et al., 2009; } \\
\text { Jedermann et al., 2009) }\end{array}$ & & $\begin{array}{l}\text { Cold chain (Amador et al., 2009) } \\
\text { Food Chain (Amador and Emond, } \\
\text { 2010) }\end{array}$ & $\begin{array}{l}\text { Cold chain (Amador et al., } \\
\text { 2009) }\end{array}$ \\
\hline Active & & & $\begin{array}{l}\text { Intermodal } \\
\text { transport } \\
\text { (Laniel et al., } \\
\text { 2008) }\end{array}$ & & $\begin{array}{l}\text { Cold chain (Gras, 2006) } \\
\text { Precision agriculture } \\
\text { (Vellidis et al., 2008) } \\
\text { Automatic machine } \\
\text { identification (Sjolander } \\
\text { et al., 2011) }\end{array}$ \\
\hline
\end{tabular}

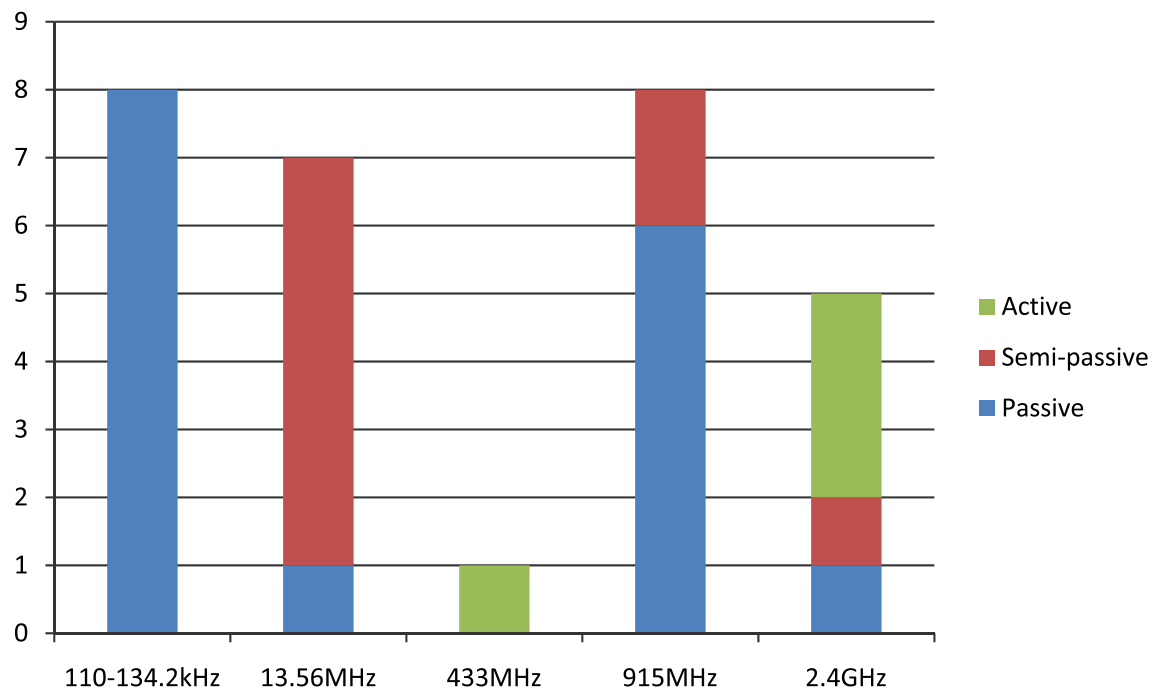

Fig. 1. RFID applications in agriculture by power source and frequency.

and trace not only large and expensive products, but small and cheap ones, creating a new generation of intelligence products (Meyer et al., 2009). This traceability control can be improved implementing RFID in combination with mobile phones and web based network computing (Sugahara, 2009). Also, the concept of "cold traceability" has been introduced to trace groups of temperature-sensitive products are transported in different atmosphere requirements (Ruiz-Garcia et al., 2009).

The link between RFID sensing devices and improved cool chain management methods such as the Quality Oriented Tracking and Tracing Systems (QTT) offer new features (Scheer, 2006). An example of this approach is the Safety Monitoring and Assurance System (SMAS) that was developed to reduce customers' risk of consuming microbiologically contaminated meat (Koutsoumanis et al., 2005). A retailer that knew which of the cases had the shorter shelf life could put it out before the one with the longer shelf life. This is known as FEFO (First Expire, First Out) (Emond and Nicometo, 2006).

Another possibility of improving the traceability in the food supply chains is the integration of RFID in packaging. Embedding an RFID inlay within the structure of a package, corrugated case or folding carton allow the development of "smart packaging" (Yam et al., 2005). However, readability tests show that RFID would be affected by aluminum, cardboard, glass, and even stretch and bubble wrap. Also, if a corrugated cardboard gets wet, the read rates for tags on or in the boxes fall more than 50\% (Roberti, 2005). 
Table

Classification of RFID tags by frequency and best potential use.

\begin{tabular}{|c|c|c|c|c|c|c|c|c|}
\hline \multirow[t]{2}{*}{ Frequency band } & \multirow[t]{2}{*}{$\begin{array}{l}\text { Common } \\
\text { frequency }\end{array}$} & \multirow[t]{2}{*}{ Tag type } & \multicolumn{2}{|c|}{$\begin{array}{l}\text { Communication } \\
\text { range }\end{array}$} & \multirow[t]{2}{*}{$\begin{array}{l}\text { Allowed field strength } \\
\text { transmission power }\end{array}$} & \multirow[t]{2}{*}{ Potential uses } & \multirow[t]{2}{*}{ Advantages } & \multirow[t]{2}{*}{ Disadvantages } \\
\hline & & & Typical & Maximum & & & & \\
\hline $\begin{array}{l}\text { Low Frequency } \\
\text { (LF) }\end{array}$ & $\begin{array}{l}125- \\
134.2 \mathrm{KHz}\end{array}$ & Passive & $20 \mathrm{~cm}$ & $100 \mathrm{~cm}$ & $72 \mathrm{~dB} \mu \mathrm{A} / \mathrm{m} \max$ & $\begin{array}{l}\text { Animal identification, food } \\
\text { traceability, tree implants, item } \\
\text { tracking }\end{array}$ & $\begin{array}{l}\text { Less prone to interference especially } \\
\text { from biological tissue and liquids. The } \\
\text { frequency band is available in most } \\
\text { countries }\end{array}$ & $\begin{array}{l}\text { Low Frequency signals require long } \\
\text { antennas and are generally larger and } \\
\text { more expensive than Higher- } \\
\text { Frequency alternatives. These tags } \\
\text { are inductively powered, and because } \\
\text { of this, the reader power must } \\
\text { increase greatly for modest } \\
\text { improvements in range }\end{array}$ \\
\hline $\begin{array}{l}\text { High Frequency } \\
\text { (HF) }\end{array}$ & $13.56 \mathrm{MHz}$ & $\begin{array}{l}\text { Passive and } \\
\text { semi-passive }\end{array}$ & $10 \mathrm{~cm}$ & $1.5 \mathrm{~m}$ & $60 \mathrm{~dB} \mu \mathrm{A} / \mathrm{m}$ & $\begin{array}{l}\text { Animal identification, cold chain } \\
\text { tracking, temperature measuring }\end{array}$ & $\begin{array}{l}\text { These tags can have shorter antennas } \\
\text { than LF tags and greater range. } \\
\text { Frequency band available worldwide }\end{array}$ & $\begin{array}{l}\text { Same physical limitations than the } \\
125 \mathrm{kHz} \text { tags because they are also } \\
\text { inductively powered }\end{array}$ \\
\hline \multirow[t]{2}{*}{$\begin{array}{l}\text { Ultra High } \\
\text { Frequency } \\
\text { (UHF) }\end{array}$} & $433 \mathrm{MHz}$ & Active & $3 \mathrm{~m}$ & $10 \mathrm{~m}$ & $10-100 \mathrm{~mW}$ & $\begin{array}{l}\text { Farm machinery, intermodal } \\
\text { transport, crop monitoring }\end{array}$ & $\begin{array}{l}\text { Available worldwide. Greater range } \\
\text { than LF and HF. Less problems with } \\
\text { metals and liquids in comparison to } \\
860 \text { and } 915 \mathrm{MHz}\end{array}$ & $\begin{array}{l}\text { A shorter wavelength due to the } \\
\text { higher frequency makes them more } \\
\text { susceptible to interference. Battery } \\
\text { limitations }\end{array}$ \\
\hline & $\begin{array}{l}860 \mathrm{MHz} \\
\text { Europe } \\
915 \mathrm{MHz} \\
\text { USA }\end{array}$ & $\begin{array}{l}\text { Active and } \\
\text { passive }\end{array}$ & $3 \mathrm{~m}$ & $15 \mathrm{~m}$ & $0.1-4 \mathrm{~W}$ & $\begin{array}{l}\text { Cold chain monitoring, traceability } \\
\text { control }\end{array}$ & $\begin{array}{l}\text { A higher frequency means that these } \\
\text { tags are potentially more powerful } \\
\text { and can therefore have a greater } \\
\text { range }\end{array}$ & $\begin{array}{l}\text { More interference. Different bands } \\
\text { available in USA and Europe. Japan } \\
\text { and China do not allow transmissions } \\
\text { in this band }\end{array}$ \\
\hline \multirow[t]{2}{*}{$\begin{array}{l}\text { Microwave } \\
\text { (MW) }\end{array}$} & $2.4 \mathrm{GHz}$ & $\begin{array}{l}\text { Passive and } \\
\text { active }\end{array}$ & $3 \mathrm{~m}$ & $30 \mathrm{~m}$ & $0.5-4 \mathrm{~W}$ & $\begin{array}{l}\text { Pallet and container tracking, farm } \\
\text { machinery. }\end{array}$ & $\begin{array}{l}\text { Worldwide availability. More } \\
\text { powerful than UHF }\end{array}$ & $\begin{array}{l}\text { Potential interference even more } \\
\text { likely than with the other UHF tags. } \\
\text { The band is shared by other } \\
\text { technologies (Bluetooth, Wi-fi, GSM, } \\
\text { etc.) }\end{array}$ \\
\hline & $5.8 \mathrm{GHz}$ & & & & & $\begin{array}{l}\text { Long range applications, fleet } \\
\text { management, Climate monitoring }\end{array}$ & $\begin{array}{l}\text { Worldwide availability. Less crowded } \\
\text { than } 433 \mathrm{MHz}, 868 \mathrm{MHz}, 928 \mathrm{MHz} \\
\text { and } 2.4 \mathrm{GHz} \text {. Smallest Fresnel } \\
\text { diffraction zone. Very small tag/ } \\
\text { antenna size }\end{array}$ & $\begin{array}{l}\text { Requires sensitive receivers. Requires } \\
\text { advanced system designs }\end{array}$ \\
\hline
\end{tabular}




\subsection{Animal identification and tracking}

Modern animal production has changed in recent years due to the use of precision tools. Results of recent research have been used as inputs to preventive diagnostics and development of decision-making software in several areas, as well as to predict events. This section provides information on current RFID animal tracking technology, how it works, current applications, and possible future directions.

In a global environment, awareness, fear and recognition of animal borne diseases (e.g. bovine spongiform encephalopathy, foot and mouth disease) have fuelled the development and implementation of reliable and effective systems for individual identification and tracking of livestock. Due to the fast movement of animals and animal food products, it is essential for the administration to be able to have "rapid trace-back" capability. Permanent identification also helps the farmer to manage more animals to be cost effective, provides better proof of ownership to reduce stock theft and improves transparency maintaining consumer confidence in animal products (Trevarthen, 2007).

RFID systems have been effective tools in identifying, tracking and monitoring livestock. Since the first patents were developed (Hanton and Leach, 1981; Morrison and Curkendall, 2001), electronic identification of cattle with RFID has been more and more used and now is a common practice in many farms (Munak, 2006). The development of a clear family of standards have helped this adoption (ISO, 1996, 2003, 2004). An RFID system can also track livestock transportation being faster, cleaner and easier than the conventional systems. A recent study shows how RFID can give transparency in poultry shipments, detecting unauthorized openings and recording the timestamp of each checkpoint passed along the path of transportation (Chansud et al., 2008; Wisanmongkol and Pongpaibool, 2009).

Traditional forms of animal identification are considered inferior in comparison to RFID technology (Trevarthen, 2007). Traditional ear tags are lost $5-60 \%$ of the time, while brands or tattoos on cattle can be damaged or fade away. Traditional systems require visual detection and must be recorded manually, which can easily introduce human errors, while the labor cost of such a practice is also high. Reading errors are estimated to occur in six of every 100 animals processed via traditional mechanisms, while RFID devices are estimated to produce only one error for every 1000 animals (Trevarthen, 2007). There are four basic ways for attaching RFID transponders to the animals: collar transponder, ear tags, injecting tiny glass transponders under the animal's skin, or via a 'bolus' where the RFID transponder is mounted within an acid resistant, cylindrical housing which is inserted permanently within the animals stomach (Finkenzeller, 2004). New developments achieve smaller tags of just a couple of centimeters and with a reading range of $1 \mathrm{~m}$ (Mun Leng et al., 2005).

In combination with herd management software, RFID animal identification systems can include detailed information like records of medical treatments, animal growth performance data, pasture performance data, movement of animals, purchase and sale dates, and carcass feedback data. The reader can be connected to a remote host computer, providing and effective data collection and database management methodology sharing data between the producer, the stockman, the packer or the veterinarian (Curkendall, 2002). Also, through the use of electronic animal identification subsidies based on the number of animals or their genetic background can be allocated properly, electronic feeding stations can be implemented or tracing back of stolen stock (Voulodimos et al., 2010).

Last studies allow simultaneous animal identification of small animals like piglets, using anti-collision systems that bring multiple access handling and prevent the collision of transponder data within the reading range of a RFID reader, which would render data unreadable (Reiners et al., 2009).

\subsection{Other livestock applications}

RFID has been used as a new technique for measuring core body temperature. RFID sensing devices can be injected into the animal (under the skin), and provide temperature readings when interrogated by an RFID reader (Opasjumruskit et al., 2006). Application tests have been performed in horses (Marsh et al., 2008), poultry, beef and dairy cattle, showing good accuracy, resolution and response time for temperature measurement (Brown-Brandl et al., 2003). Manufacturers are looking to improve this technology in the future, in order to provide information on an animal's hormonal changes, blood pressure and even possibly disease identification (Hostettor, 2003). Also, the chewing and ruminating behaviors can be studied by the implementation of wireless automatic systems, addressing the dietary factors affecting normal rumen function of dairy cows (Kononoff et al., 2002; Schirmann et al., 2009).

\subsection{Precision agriculture}

The development of RFID applications in precision agriculture makes possible to increase efficiencies, productivity and profitability while minimizing unintended impacts on wildlife and the environment, in many agricultural production systems. Moreover, the real time information from the fields will provide a solid base for farmers to adjust strategies at any time. Instead of take decisions based in some hypothetical average condition, which may not exist anywhere in the reality, a precision farming approach recognizes differences and adjusts management actions accordingly (USC, 2006). Since installation of RFID is easier than existing wired solutions, sensors can be more densely deployed to provide local detailed data. For this purpose, Hamrita and Hoffacker (2005) developed a lab prototype for wireless measurement of soil temperature. The system was based in a commercial $13.56 \mathrm{MHz}$ RFID tag. Measurements showed a high correlation (greater than 99\%) with those obtained using a thermocouple (Hamrita and Hoffacker, 2005). Vellidis et al. (2008) used active tags of $2.4 \mathrm{GHz}$ for the developed "smart sensor nodes" that included an array of soil moisture and temperature sensors (Vellidis et al., 2008). This type of information is very important for scheduling irrigation, because instead than irrigating an entire field in response to broad sensor data, each section could be activated based on local sensors.

In greenhouses, RFID can be used for tracking items like pots (Barge et al., 2010) or for remote sensing like Yang et al. (2008) did. Their system incorporated RFID technology with spectral imaging and environmental sensing in a greenhouse. Greenhouse temperature, relative humidity, and lighting conditions were measured above the crop (Yang et al., 2008).

Where GPS data may be unavailable due to foliage, like in orchards, RFID can be used for matching bins harvested fruits with corresponding trees, during harvesting in orchards (Ampatzidis and Vougioukas, 2009). For tree identification, tags can also be implanted in the trunks without significant effect on plant health, growth and production. These tests have been done in citrus, grapevine plants and Prunus spp. (Bowman, 2010; Luvisi et al., 2010a; Luvisi et al., 2011). The marked plants can be monitored, and will be able to supply some information, including identity, growth parameters, susceptibility to biotic stress factors and productivity. All information is available by a website accessing a database, guaranteeing that users can use online access to retrieve information (Luvisi et al., 2010b).

RFID implemented in off-road vehicles, such as tractors or combine harvester, can allow exchanging data with static 
infrastructure or with other vehicles, creating mobile RFID systems and helping fleet management (Sjolander et al., 2011). The tags can be also attached to the products (seeds, fertilizers, pesticides, etc.) and the readers installed in the machinery, detecting what is put into the implement's hopper or tank. Transparency is gained for the purpose of quality assurance, knowing which fertilizer was spread or when, and which pesticides or insecticides were used (Watts and Miller, 2002; Peets et al., 2009).

\subsection{Cold chain applications}

Every day, millions of tons of temperature sensitive goods are produced, transported, stored or distributed worldwide. For all these products the control of temperature is essential. Several applications for monitoring cold chain logistics by means of RFID have been reported. The majority are oriented to perishable food products. Here are the most representative to our knowledge.

The use of microbial growth models combined with information from active RFID has been faced. These models allow the prediction of microbiological safety and quality of foods, by monitoring the environment without recourse to further microbiological analysis. Thus immediate decisions on the quality and/or safety of fresh produce can be made based on the temperature profile of the supply chain (McMeekin et al., 2006).

Ogasawara and Yamasaki (2006) reported a cold chain solution that uses RFID tags with embedded temperature sensors. It also introduced a temperature-managed traceability starter kit that contributes to effective risk management by easily enabling consistent temperature management throughout transportation processes (Ogasawara and Yamasaki, 2006). Gras (2006) monitored a cold chain of frozen goods using semi-passive and active RFID instrumented with temperature sensors. The experimental work covered four steps of the cold chain: production, transportation, storage and delivery (Gras, 2006).

Environmental temperatures can differ depending in the location of the logger, packing material or heat dissipation of the product (Moureh et al., 2002; Raab et al., 2008). In a refrigerated transport the tags can be installed in the walls, the pallets or the boxes. Jedermann et al. (2009) monitored 16 trucks putting the tags in the wall. They used $13.56 \mathrm{MHz}$ semi-passive tags instrumented with temperature sensor (Jedermann et al., 2009). If the tags are inside the pallets, an critical issue is the readability. Amador and Emond, 2010 studied the readability of different tag configurations inside pallets of military meals, achieving a RFID temperature tracking system, able to monitor $85 \%$ of the temperatures of the pallet (Amador and Emond, 2010). Other studies, like Amador et al. (2009) or Abad et al. (2009) installed the tags in the boxes, reading the tags without the need of opening and obtaining more accurate measurements (Abad et al., 2009; Amador et al., 2009). However, the most accurate one is the temperature of the product and it is possible to measure it using temperature tags with probes (Amador et al., 2009).

Today's regulations do not allow RFID to be utilized inside aircrafts during flight, but the need for real time cold chain management is pushing the air cargo industry to investigate the capabilities of this technology. In this framework, the interactions between RFID and air cargo container materials have been studied doing test with five different aircraft containers (Aluminum, Duralite, Herculite, $\operatorname{Kevlar}^{\circledR}$ and Lexan $^{\circledR}$ ) and 3 frequencies $(433 \mathrm{MHz}$, $915 \mathrm{MHz}$ and $2.45 \mathrm{GHz}$ ) (Laniel et al., 2010).

In the intermodal transportation, the performance of radio waves inside metal enclosed areas was studied. Laniel et al. (2008) focuses on the 3-D mapping of RFID signal strength inside a $12 \mathrm{~m}\left(40^{\prime}\right)$ refrigerated marine container. Results shown that wave propagation was significantly higher at $433 \mathrm{MHz}$ than at $915 \mathrm{MHz}$ or $2.4 \mathrm{GHz}$ (Laniel et al., 2008). At $433 \mathrm{MHz}$ the wavelength is approximately a meter, enabling signals to diffract around obstructions. At $2.4 \mathrm{GHz}$ the diffraction is very limited and therefore not recommended for most cold chain applications which are in crowded environments (Technologies, 2008).

\section{Challenges and limitations}

RFID itself is not a very new technology, but its commercial use is very recent. Thus, implementing RFID involves a multitude of challenges.

\subsection{Harsh environments}

In agricultural applications, RFID is often exposed to harsh environments with excessive dirt, dust, moisture, and they must function in both extreme heat and cold, from $-30^{\circ}$ to $70^{\circ}$. Haapala (2008) validated the performance of electronic identification tags for animals, under extremely cold temperature $\left(-25^{\circ} \mathrm{C}\right.$ ) (Haapala, 2008). Moreover, in the food industry tags should withstand the pasteurization process, boiling point temperatures, X-ray and gamma radiation, which is commonly used for sterilization. Advances in RFID make the technology more useful to food processors with new developments, like the gamma sterilizable tags now available, with a resistant up to 500 kilogray (kGy) of gamma energy (Andrechak and Wiens, 2008).

\subsection{Huge volumes of data}

One limitation might be that these monitoring systems create huge volumes of data that are difficult to manage, causing a huge increase in the daily volume of data in a corporate information technology system. An RFID implementation can generate 10100 times more information than traditional barcode technology. Database administrators need to be able to deal with the potential stresses on the databases, both in terms of speed and volume. Thus, the solution lies in implementing a decentralized data management system. Data can be pre-processed and duplicate information eliminated close to their point of origin by intelligent systems, which could be sited at the level of the tag or reader (Roberti, 2003; Ruiz-Garcia, 2008).

\subsection{Reading range}

The read range performance of tags differs extraordinarily. Radio propagation in real environments is complex due to multipath propagation, shadowing and attenuation. In agriculture, the radio frequency faces challenges due to placement of nodes for wide-area mesh coverage and reliable link quality above crop canopies. RFID must be able to operate in a wide range of environments such as bare fields, vineyards, orchards, from flat to complex topography and over a range of weather conditions, all of which affect radio performance (Andrade-Sanchez et al., 2007). In these situations, the link power budget is dependent on crop growth and terrain in addition to more common factors such as node spacing and antenna height (Tate et al., 2008). For applications inside buildings like burns, greenhouses or warehouses, the radio signal has to go through many objects like walls, windows, pallets, machines, etc. which also cause a significant reduction in signal strength.

\subsection{Fault detection and isolation}

An important research topic that must be faced is fault detection and isolation. In a remote sensing application it is essential to detect the erroneous measurements. False reads can be done as a result of radio waves being distorted, deflected, absorbed, 
and interfered with. Wrong information provided by the monitoring system should be identified and skipped. Also the implementation of artificial intelligence in the core of the system can block the transmission of erroneous data (Angeles, 2005).

\subsection{Physical limitations}

Another important issue is to deal with the physical limitations of RFID. Metals and liquids inhibit the propagation of electromagnetic waves. This is particularly true for UHF and microwave frequencies $(2.4 \mathrm{GHz})$. Some temperature sensitive products such as fruits, vegetables or juices have high water content, sometimes more than $90 \%$. As a result, performance can be affected by the item on which the tag is attached (Angeles, 2005; Ruiz-Garcia, 2008). However, reflections and product dimensions are important for liquid and dielectric materials as well since much of the power loss occurs at the interfaces between air and the medium (Fletcher et al., 2005). Moreover, the last generation of Class 4 RFID tags can be configured in a mesh network. In this type of network, the tags can communicate each other to get to a reader circumventing environmental obstacles and extend the size of the system (Engels and Sarma, 2005).

\subsection{Standards}

RFID and EPCglobal have defined a series of standards (see Tables 4 and 5), but the situation is complicated. There is a proliferation of incompatible standards with major RFID vendors offering proprietary systems. For example, in the case of UHF, in Europe the bandwidth ranges from 865 to $868 \mathrm{MHz}$, in USA from 902 to $928 \mathrm{MHz}$ and China has approved two different bandwidths, one from 840.25 to $844.75 \mathrm{MHz}$ and the other one fro, 920.25 to 924.75 MHz (Roberts, 2006).

The lack of uniformity in global standards makes the RFID implementations more difficult. Conventional readers do not read tags at different frequencies. Thus, managing multiple readers and related hardware can be a challenge, especially across multiple facilities. However, a new generation of multi-frequency readers has been developed recently. These readers are called "agile" and can operate at the same time at different bands (Mallison, 2005).

\subsection{Level of granularity}

The level of granularity is a limitation in most of the applications. Normally three levels of granularity are considered: pallet, case or

Table 4

ISO standards related with RFID.

\begin{tabular}{|c|c|}
\hline $\begin{array}{l}\text { Animal } \\
\text { identification }\end{array}$ & ISO 11784 , ISO 11785, ISO 14223 \\
\hline Item management & $\begin{array}{l}\text { ISO/IEC 14443, ISO/IEC 15961, ISO/IEC 15962, ISO/IEC } \\
15693, \text { ISO/IEC } 18000\end{array}$ \\
\hline $\begin{array}{l}\text { Real time locating } \\
\text { systems }\end{array}$ & ISO/IEC 24730 \\
\hline Freight containers & ISO 18185, ISO 23389 \\
\hline
\end{tabular}

item-level. The primary advantage of case or item-level tagging over pallet-level tagging is more detailed and accurate information, since each pallet in a load and each carton on a pallet can experience temperature variations. Instead of reject an entire shipment goods can be considered on a pallet-by-pallet or case-by-case basis. But high granularity also means much more tags to handle with, higher costs and huge data to be processed (Angeles, 2005).

\subsection{Cost}

Cost is a major hurdle in the widespread use of RFID technology in agriculture. An average RFID costs roughly 20-30 cents per tag, which is too costly for some products with only 50 cents value such as fruits and vegetables. They are still expensive as compared to a barcode label, which costs less than 1 cent. Thus, this higher cost of RFID makes it uneconomical to incorporate tags into every retail item (Roberts, 2006).

\subsection{Lack of skilled personnel}

The lack of skilled personnel is another limitation in many agricultural implementations. Many companies have no qualified personnel for this purpose; there is a shortfall between the supply of talent and the market demand. The expansion of RFID in agriculture requires more agriculture engineers, computer scientists and technicians with RFID skills.

\subsection{Information sharing}

Information sharing is probably one of the greatest challenges, but is essential for achieving a trustable and efficient traceability control in Agriculture. Obtaining the required level of trust and cooperation across the supply chain, collaboration with supply chain partners both up and down the chain, is necessary. However, there is a strong resistance to share information on applications that depend on data from various trading partners, information sharing issues must be resolved to achieve maximum benefit.

\subsection{Integration with chemical sensors}

One of the current challenges in smart tags is the integration of chemical sensors onboard of flexible tags (Abad et al., 2009). In the case of fruit logistics, volatile compounds like ethanol and ethylene are very important to detect and quantify (Ruiz-Garcia, 2010). Resistive sensors such as Metal Oxide Sensors (MOS) for volatile evaluation have been developed into commercial MEMS (Microelectromechanical systems) by means of the development of Ultra Low Consumption Hot plates which allow the reduction of the size of the sensor and thus the power required for proper operation. But this technology has it main drawback in the lack of specificity of sensor (Wise, 2007).

Vergara et al. (2006) developed an RFID reader with onboard micro-machined metal oxide gas sensors aimed at monitoring concentration of gases, such as acetaldehyde or ethylene during fruit transport and vending. The developed platform integrates a

Table 5

RFID standards as applied to frequency.

\begin{tabular}{|c|c|c|c|c|c|}
\hline & $\begin{array}{l}\text { Low frequency } \\
125-134.2 \mathrm{kHz}\end{array}$ & $\begin{array}{l}\text { High frequency } \\
13.56 \mathrm{MHz}\end{array}$ & $\begin{array}{l}\text { High frequency } \\
433 \mathrm{MHz}\end{array}$ & $\begin{array}{l}\text { Ultra high frequency } \\
860-915 \mathrm{MHz}\end{array}$ & $\begin{array}{l}\text { Ultra high frequency } \\
2.4 \mathrm{GHz}\end{array}$ \\
\hline \multirow[t]{3}{*}{ ISO } & ISO 11784 & ISO/IEC 14443 & ISO $18000-7$ & ISO $18000-6 \mathrm{~A}$ & ISO $18000-4$ \\
\hline & ISO/IEC $18000-2 \mathrm{~A}$ & ISO/IEC 15693 & & ISO $18000-6 B$ & ISO/IEC 24730-2 \\
\hline & ISO/IEC $18000-2 \mathrm{~B}$ & ISO 18000-3 & & ISO $18000-6 C$ & \\
\hline \multirow[t]{2}{*}{ EPCglobal } & & Class 1 & & Class 0 & \\
\hline & & & & Class 1 & \\
\hline
\end{tabular}


commercial off the shelf inductive coupling RF transceiver in the $13.56 \mathrm{MHz}$ band, fully compliant with the ISO15693 standard, micro-hotplate gas sensors, driving and readout electronics (Vergara et al., 2006).

\subsection{Recycling issues}

As the use of RFID grows, the potential environmental impact of this kind of devices should be taken into account (Roberts, 2006). There is a need of specific recycling programs. Moreover, when RFID tags are attached or embedded within products and not properly removed, the effects on the recycling process could be serious. Adhesives, computer chips, pieces of metal from antennae, and conductive inks of an RFID tag can affect the process of recycling paper, glass, plastic, and metal (Foley, 2006; Thomas, 2008).

\section{Conclusions and future trends}

While the technology has been available for several decades, the 21 st century has marked the beginning of a new era in RFID development and usage. Actually, the applications of RFID in agriculture are many and varied. Some of them, like traceability control or livestock identification, are very common and widespread. However, a significant proportion of RFID deployments in other fields remain exploratory.

Despite all the challenges and limitations, the use of RFID in agriculture and food industry provides new features that have the potential to be an economically viable, speeding up operations and improving data accuracy. The value of technology can be best realized when integrated with agronomic knowledge, using the information gathered in the improvement of decision support systems. Also improving operations by providing early warning of equipment failure and a predictive maintenance tool, improving energy management, providing automatic record-keeping for regulatory compliance, eliminating personnel training costs or reducing insurance costs. The collaboration and synergy of sensing, processing, communication and actuation is the next step to exploit the potential of these technologies.

From 2004 to 2011 the evolution of RFID technology has been developed very fast, adding new features to traditional automatic identification and data capture applications. An important benefit of the systems is the visibility that it can give along the food chain. Measurements obtained are consistent and provide valuable information on the conditions encountered during the life cycle of the products. Another advantage is providing effective support in legal situations as well as safety inspections.

RFID is still a relatively young market with good growth potential. The number of applications is expected to grow in the next years. As a general trend, innovation rather than cost reduction has become the driver for RFID adoption. Industry and academic research and development on RFID will continue in the near future. Focusing in the most important needs, like: improving readability of RFID tags in any situation, developing low cost RFID tags (less than 1 cent), proper integration of RFID data collection with decision support tools, evolution of the standards (including ISO and EPC), longer battery life in active tags, more variety of sensors and improved processing capabilities.

\section{References}

Abad, E., Palacio, F., Nuin, M., González de Zárate, A., Juarros, A., Gómez, J.M., Marco, S., 2009. RFID smart tag for traceability and cold chain monitoring of foods: demonstration in an intercontinental fresh fish logistic chain. Journal of Food Engineering 93 (4), 394-399.

Amador, C., Emond, J. P., Nunes, M. C., 2008. Application of RFID technologies in the temperature mapping of the pineapple supply chain. In: Food Processing Automation Conference. Providence, Rhode Island, USA.
Amador, C., Emond, J.P., Nunes, M.C.N., 2009. Application of RFID technologies in the temperature mapping of the pineapple supply chain. Sensing and Instrumentation for Food Quality and Safety 2009 (3), 26-33.

Amador, C., Emond, J.P., 2010. Development of RFID temperature tracking systems for combat feeding logistics. In: XVIIthWorld Congress of the International Commission of Agricultural and Biosystems Engineering (CIGR), CSBE/SCGAB. Quebec City, Canada.

Ampatzidis, Y.G., Vougioukas, S.G., 2009. Field experiments for evaluating the incorporation of RFID and barcode registration and digital weighing technologies in manual fruit harvesting. Computers and Electronics in Agriculture 66 (2), 166-172.

Andrade-Sanchez, P., Pierce, F. J., Elliot, T.V., 2007. Performance assessment of wireless sensor networks in agricultural settings. In: 2007 ASABE Annual International Meeting Minneapolis, Minnesota, USA.

Andrechak, G., Wiens, R.A., 2008. Hitachi $\mu$-chip RFID technology compatible with gamma sterilization. <http://www.nordion.com/documents/uChip-GammaWhite-Paper.pdf>.

Angeles, R., 2005. RFID technologies: supply-chain applications and implementation issues. Information Systems Management 22 (1), 51-65.

Attaran, M., 2007. RFID: an enabler of supply chain operations. Supply Chain Management-an International Journal 12 (4), 249-257.

Barge, P., Gay, P., Piccarolo, P., Tortia, C., 2010. RFID tracking of potted plants from nursery to distribution. In: International Conference Ragusa SHWA2010. Ragusa Ibla Campus, Italy.

Bowman, K.D., 2010. Longevity of radiofrequency identification device microchips in citrus trees. Hortscience 45 (3), 451-452.

Brown-Brandl, T.M., Yanagi, T., Xin, H., Gates, R.S., Bucklin, R.A., Ross, G.S., 2003. A new telemetry system for measuring core body temperature in livestock and poultry. Applied Engineering in Agriculture 19 (5), 583-589.

Chang, K., Kim, Y.H., Kim, Y., Yoon, Y.J., 2007. Functional antenna integrated with relative humidity sensor using synthesised polyimide for passive RFID sensing. Electronics Letters 43 (5), 259-260.

Chansud, W., Wisanmongkol, J., Ketprom, U., 2008. RFID for Poultry Traceability System at Animal Checkpoint. Paper read at Electrical Engineering/Electronics, Computer, Telecommunications and Information Technology, 2008. ECTI-CON 2008. 5th International Conference on, 14-17 May 2008.

Cho, N., Song, S. J., Kim, S., Yoo, H.J., 2005. A 5.1-mu W UHF RFID tag chip integrated with sensors for wireless environmental monitoring. Esscirc 2005. In: Proceedings of the 31st European Solid-State Circuits Conference, pp. 279-282.

Curkendall, L.D., 2002. Method and Apparatus for a Livestock Data Collection and Management System. Aginfolink Technologies Inc., USA.

ECPGlobal, 2008. EPC Radio Frequency Identity Protocols Class-1 Generation-2 UHF RFID. Protocols for Communications at $860-960 \mathrm{MHz}$.

Emond, J.P., Nicometo, M., 2006. Shelf-life prediction and FEFO inventory management with RFID. In: Cool Chain Association Workshop. Temperature Measurements-When, Where and How? Knivsta, Sweden.

Engels, D.W., Sarma, S.E., 2005. Standardization requirements within the RFID class structure framework. <http://www.autoidlabs.org/uploads/media/ AUTOIDLABS-WP-SWNET-011.pdf>.

Finkenzeller, K., 2004. RFID Handbook Radio-Frequency Identification Fundamentals and Applications, second ed. John Wiley \& Sons, England.

Fletcher, R., Marti, U.P., Redemske, R., 2005. Study of UHF RFID signal propagation through complex media. In: Antennas and Propagation Society International Symposium, 2005 IEEE.

Foley, C., 2006. Radio frequency identification (RFID) tags copper content detrimental to recycling. <http://www.recyclingtech.org/>.

Gras, D., 2006. RFID Based Monitoring of the Cold Chain. Paper Read at 2nd international Workshop Cold Chain Management at Bonn, Germany.

Haapala, H.E.S., 2008. Operation of RFID in cold environment. In: Livestock Environment VIII. ASABE, Iguassu Falls, Brazil.

Hamrita, T.K., Hoffacker, E.C., 2005. Development of a "smart" wireless soil monitoring sensor prototype using RFID technology. Applied Engineering in Agriculture 21 (1), 139-143.

Hanton, J.P., Leach, H.A., 1981. Electronic livestock identification system. Patent no. 4262632. United States Patent.

Hostettor, J., 2003. Animal-tracking chips now let you in on how Fido is feeling. USA Today. <http://www.usatoday.com/tech/news/techinnovations/2003-04-21animal-chip_x.htm>.

ISO, 1996. 11785 Radio Frequency Identification of Animals-Technical Concept. International Organization for Standardization.

ISO, 2003. 14223 Radiofrequency Identification of Animals-Advanced Transponders. International Organization for Standardization.

ISO, 2004. 11784 Radio Frequency Identification of Animals-Code Structure. International Organization for Standardization.

Jedermann, R., Behrens, C., Westphal, D., Lang, W., 2006. Applying autonomous sensor systems in logistics - combining sensor networks, RFIDs and software agents. Sensors and Actuators A: Physical 132 (1), 370-375.

Jedermann, R., Ruiz-Garcia, L., Lang, W., 2009. Spatial temperature profiling by semi-passive RFID loggers for perishable food transportation. Computers and Electronics in Agriculture 65 (2), 145-154.

Jones, P., Clarke-Hill, C., Shears, P., Comfort, D., Hillier, D., 2004. Radio frequency identification in the UK: opportunities and challenges. International Journal of Retail \& Distribution Management 32 (3), 164-171.

Kononoff, P.J., Lehman, H.A., Heinrichs, A.J., 2002. Technical note - a comparison of methods used to measure eating and ruminating activity in confined dairy cattle. Journal of Dairy Science 85 (7), 1801-1803. 
Koutsoumanis, K., Taoukis, P.S., Nychas, G.J.E., 2005. Development of a safety monitoring and assurance system for chilled food products. International Journal of Food microbiology 100 (1-3), 253-260.

Laniel, M., Emond, J.P., Altunbas, A.E., 2008. RFID behavior study in enclosed trailer/ container for real time temperature tracking. In: Food Processing Automation Conference. Providence, Rhode Island, USA.

Laniel, M., Uysal, I., Emond, J.P., 2010. Radio frequency interactions with air cargo container materials for real time cold chain monitoring. In: XVIIthWorld Congress of the International Commission of Agricultural and Biosystems Engineering (CIGR). C.S.f.B. (CSBE/SCGAB), Québec City, Canada.

Luvisi, A., Panattoni, A., Bandinelli, R., Rinaldelli, E., Pagano, M., Gini, B., Triolo, E. 2010a. RFID microchip internal implants: Effects on grapevine histology. Scientia Horticulturae 124 (3), 349-353.

Luvisi, A., Triolo, E., Rinaldelli, E., Bandinelli, R., Pagano, M., Gini, B., 2010b. Radiofrequency applications in grapevine: from vineyard to web. Computers and Electronics in Agriculture 70 (1), 256-259.

Luvisi, A., Panattoni, A., Bandinelli, R., Rinaldelli, E., Pagano, M., Triolo, E., 2011. Implanting RFIDs into Prunus to facilitate electronic identification in support of sanitary certification. Biosystems Engineering 109 (2), 167-173.

Mallison, H., 2005. An Overview of Location and Identity Technologies. A.-I. Labs: Auto-ID Center, Institute for Manufacturing Department of Engineering, University of Cambridge.

Marsh, J.R., Gates, R.S., Day, G.B., Aiken, G.E., Wilkerson, E.G., 2008. Assessment of an Injectable RFID Temperature Sensor for Indication of Horse Well-Being. In ASABE Annual International Meeting 2008. Rhode Island, USA.

McMeekin, T., Smale, N., Jenson, I., Tanner, D., 2006. Microbial Growth Models and Temperature monitoring technologies. Paper Read at 2nd International Workshop Cold Chain Management, 8-9 May 2006 at Bonn, Germany.

Meyer, G.G., Främling, K., Holmström, J., 2009. Intelligent Products: A survey. Computers in Industry 60 (2009), 137-148.

Morrison, M.J., Curkendall, L.D., 2001. Apparatus and Method for Reading Radio Frequency Identification Transponders used for Livestock Identification and Data Collection, edited by U.S. Patent. United States, Aginfolink Holdings.

Moureh, J., Laguerre, O., Flick, D., Commere, B., 2002. Analysis of use of insulating pallet covers for shipping heat-sensitive foodstuffs in ambient conditions. Computers and Electronics in Agriculture 34 (1-3), 89-109.

Mun Leng, N., Kin Seong, L., Hall, D.M., Cole, P.H., 2005. A Small Passive UHF RFID Tag for Livestock Identification. Paper Read at Microwave, Antenna, Propagation and EMC Technologies for Wireless Communications, 2005. MAPE 2005. IEEE International Symposium on, 8-12 Aug 2005.

Munak, A., 2006. Preface. In: CIGR Handbook of Agricultural Engineering Volume VI Information Technology. CIGR.

Murković, I., Steinberg, M.D., 2009. Radio frequency tag with optoelectronic interface for distributed wireless chemical and biological sensor applications. Sensors and Actuators B: Chemical 138 (1), 120-125.

Ngai, E., Riggins, F., 2008. RFID: technology, applications, and impact on business operations. International Journal of Production Economics 112 (2), 507-509.

Ngai, E.W.T., Cheng, T.C.E., Au, S., Lai, K.H., 2007. Mobile commerce integrated with RFID technology in a container depot. Decision Support Systems 43 (1), 62-76.

Ogasawara, A., Yamasaki, K., 2006. A temperature-managed traceability system using RFID tags with embedded temperature sensors. NEC Technical Journal (2), 82-86.

Opasjumruskit, K., Thanthipwan, T., Sathusen, O., Sirinamarattana, P., Gadmanee, P., Pootarapan, E., Wongkomet, N., Thanachayanont, A., Thamsirianunt, M., 2006. Self-powered wireless temperature sensors exploit RFID technology. Pervasive Computing, IEEE 5 (1), 54-61.

Peets, S., Gasparin, C.P., Blackburn, D.W.K., Godwin, R.J., 2009. RFID tags for identifying and verifying agrochemicals in food traceability systems. Precision Agriculture 10 (5), 382-394.

Raab, V., Bruckner, S., Beierle, E., Kampmann, Y., Petersen, B., Kreyenschmidt, J., 2008. Generic model of shelf life dynamics in support of cold chain management in pork and poultry supply chains. Journal on Chain and Network Science 8 (2), 59-73.

Reiners, K., Hegger, A., Hessel, E.F., Böck, S., Wendl, G., Van den Weghe, H.F.A., 2009 Application of RFID technology using passive HF transponders for the individual identification of weaned piglets at the feed trough. Computers and Electronics in Agriculture 68 (2), 178-184.

Roberti, M., 2003. Seven reasons to act now. RFID Journal. Available from: $<$ www.rfidjournal.com/article/view/589>.

Roberti, M., 2005. Beware of RFID's Hysteresis Effect. RFID Journal.
Roberts, C.M., 2006. Radio frequency identification (RFID). Computers \& Security 25 (1), 18-26.

Ruiz-Garcia, L., 2008. Development of Monitoring Applications for Refrigerated Perishable Goods Transportation, Ingenieria Rural. Universidad Politécnica de Madrid, Madrid.

Ruiz-Garcia, L., Steinberger, G., Rothmund, M., 2009. A model and prototype implementation for tracking and tracing agricultural batch products along the food chain. Food Control 21 (2010), 112-121.

Ruiz-Garcia, L., 2010. Development of Monitoring Systems for Cold Chain Logistics: Improving Food Safety through Emergent Sensing Technologies in the Cold Supply Chain. LAP Lambert Academic Publishing.

Sarac, A., Absi, N., Dauzère-Pérès, S., 2010. A literature review on the impact of RFID technologies on supply chain management. International Journal of Production Economics 128 (1), 77-95.

Scheer, F.P., 2006. Optimising supply chains using traceability systems. In: Improving traceability in food processing and distribution W.p. limited. Cambridge, England.

Schirmann, K., von Keyserlingk, M.A.G., Weary, D.M., Veira, D.M., Heuwieser, W., 2009. Technical note: validation of a system for monitoring rumination in dairy cows. Journal of Dairy Science 92 (12), 6052-6055.

Sjolander, A.J., Thomasson, J.A., Sui, R., Ge, Y., 2011. Wireless tracking of cotton modules. Part 2: Automatic machine identification and system testing. Computers and Electronics in Agriculture 75 (1), 34-43.

Sugahara, K., 2009. Traceability system for agricultural productsbased on RFID and mobile technology. In: Zhao, C., Li, D. (Eds.), Computer and Computing Technologies in Agriculture II, vol. 3. Springer, Boston.

Tate, R.F., Hebel, M.A., Watson, D.G., 2008. WSN link budget analysis for precision agriculture. In: 2008 ASABE Annual International Meeting. ASABE, Providence, Rhode Island, RI, USA.

Technologies, S., 2008. Selecting the right active frequency. <http:// www.autoid.org/2002_Documents/sc31_wg4/docs_501-520/520_180007_WhitePaper.pdf.

Thomas, V.M., 2008. Environmental Implications of RFID. Paper Read at Electronics and the Environment, 2008. ISEE 2008. IEEE International Symposium on 19-22 May 2008.

Todd, B., Phillips, M., Schultz, S.M., Hawkins, A.R., Jensen, B.D., 2009. Low-cost RFID threshold shock sensors. IEEE Sensors Journal 9 (4), 464-469.

Trevarthen, A., 2007. The national livestock identification system: the importance of traceability in e-business. Journal of Theoretical and Applied Electronic Commerce Research 2 (1), 49-62.

Twist, D.C., 2005. The impact of radio frequency identification on supply chain facilities. Journal of Facilities Management 3 (3), 226-239.

USC. Precision Agriculture 2006 [cited 14/02/2009. <http://www.gpoaccess.gov/ uscode/index.html>

Vellidis, G., Tucker, M., Perry, C., Wen, C., Bednarz, C., 2008. A real-time wireless smart sensor array for scheduling irrigation. Computers and Electronics in Agriculture 61 (1), 44-50.

Vergara, A., Llobet, E., Ramírez, J.L., Ivanov, P., Fonseca, L., Zampolli, S., Scorzoni, A., Becker, T., Marco, S., Wöllenstein, J., 2006. An RFID reader with onboard sensing capability for monitoring fruit quality. In: Eurosensors 2006. Goteborg, Sweden.

Voulodimos, A.S., Patrikakis, C.Z., Sideridis, A.B., Ntafis, V.A., Xylouri, E.M., 2010. A complete farm management system based on animal identification using RFID technology. Computers and Electronics in Agriculture 70 (2), 380-388.

Want, R., 2004. Enabling ubiquitous sensing with RFID. Computer 37 (4), 84-86.

Watts, A., Miller, P., 2002. Applications of RFID (radio frequency identification) in agriculture. Pesticide Outlook 13, 254-258.

Wentworth, S.M., 2003. Microbial sensor tags. In: 2003 IFT (The Institute of Food Engineering) Annual Meeting. Chicago, Illinois, USA.

Wisanmongkol, J., Pongpaibool, P., 2009. A Passive UHF RFID tag for poultry traceability. In: The 2009 International Symposium on Antennas and Propagation (ISAP 2009). Bangkok, Thailand.

Wise, K.D., 2007. Integrated sensors, MEMS, and microsystems: reflections on a fantastic voyage. Sensors and Actuators A: Physical 136 (1), 39-50.

Yam, K.L., Takhistov, P.T., Miltz, J., 2005. Intelligent packaging: concepts and applications. Journal of Food Science 70 (1), R1-R10.

Yang, I.-C., Chen, S., Huang, Y.-I., Hsieh, K.-W., Chen, C.-T., Lu, H.-C., Chang, C.-L., Lin, H.-M., Chen, Y.-L., Chen, C.-C., Lo, Y.M., 2008. RFID-integrated multi-functional remote sensing system for seedling production management. In: 2008 ASABE Annual International Meeting. Providence, Rhode Island, USA. 